\title{
Myositis Activities Profile
}

National Cancer Institute

\section{Source}

National Cancer Institute. Myositis Activities Profile. NCI Thesaurus. Code C121358.

An assessment of disease-specific limitations of activities of daily living in patients with polymyositis and dermatomyositis. 